\title{
Decomposition dynamics of coarse woody debris of three important central European tree species
}

Steffen Herrmann ${ }^{1,2^{*}}$, Tiemo Kahl ${ }^{1}$ and Jürgen Bauhus ${ }^{1}$

\begin{abstract}
Background: Coarse woody debris (CWD) is an important element of forest structure that needs to be considered when managing forests for biodiversity, carbon storage or bioenergy. To manage it effectively, dynamics of CWD decomposition should be known.

Methods: Using a chronosequence approach, we assessed the decomposition rates of downed CWD of Fagus sylvatica, Picea abies and Pinus sylvestris, which was sampled from three different years of tree fall and three different initial diameter classes $(>10-\leq 20 \mathrm{~cm},>20-\leq 40 \mathrm{~cm},>40 \mathrm{~cm})$. Samples originating from wind throws in 1999 were collected along a temperature and precipitation gradient. Based on the decay class and associated wood densities, log volumes were converted into CWD mass and C content. Log fragmentation was assessed over one year for log segments of intermediate diameters $(>20-40 \mathrm{~cm})$ after 8 and 18 years of decomposition.

Results: Significantly higher decomposition constants ( $k$ ) were found in logs of $F$. sylvatica $\left(0.054\right.$ year $\left.^{-1}\right)$ than in $P$. abies $\left(0.033\right.$ year $\left.^{-1}\right)$ and $P$. sylvestris $\left(0.032\right.$ year $\left.^{-1}\right)$. However, mass loss of $P$. sylvestris occurred mainly in sapwood and hence $k$ for the whole wood may be overestimated. Decomposition rates generally decreased with increasing log diameter class except for smaller dimensions in P. abies. About $74 \%$ of the variation in mass remaining could be explained by decomposition time (27\%), tree species (11\%), diameter (17\%), the interactive effects between tree species and diameter (4\%) as well as between decomposition time and tree species (3\%) and a random factor (site and tree; $9.5 \%$ ), whereas temperature explained only $2 \%$.

Wood fragmentation may play a more important role than previously thought. Here, between $14 \%$ and $30 \%$ of the decomposition rates (for the first 18 years) were attributable to this process. Carbon (C) density $\left(\mathrm{mgC} \cdot \mathrm{cm}^{-3}\right.$ ), which was initially highest for F. sylvatica, followed by P. sylvestris and P. abies, decreased with increasing decay stage to similar values for all species.
\end{abstract}

Conclusions: The apparent lack of climate effects on decomposition of logs in the field indicates that regional decomposition models for CWD may be developed on the basis of information on decomposition time, tree species and dimension only. These can then be used to predict C dynamics in CWD as input for C accounting models and for habitat management.

Keywords: Dead wood; Carbon; Decay rate; Beech; Spruce; Pine

\footnotetext{
* Correspondence: steffen.herrmann@wsl.ch

${ }^{1}$ Institute of Forest Sciences, Faculty of Environment and Natural Resources, University of Freiburg, Tennenbacherstr. 4, D-79106 Freiburg, Germany ${ }^{2}$ Swiss Federal Research Institute WSL, Zürcherstrasse 111, CH-8903 Birmensdorf, Switzerland
} 


\section{Background}

Coarse woody debris (CWD) is structurally and functionally very important for forest ecosystems, in particular for biodiversity (Siitonen 2001), the energy and nutrient cycle (Müller-Using and Bartsch 2007; Kuehne et al. 2008) and carbon storage (Harmon et al. 1986; Turner et al. 1995; Pregitzer and Euskirchen 2004; Kahl et al. 2012). Whereas the amount of CWD may comprise up to $30 \%$ or even $40 \%$ of the total timber volume in natural beech (Commarmot et al. 2013) and spruce (Ranius et al. 2003) forests, this share is typically less than $5 \%$ in managed European forests (Bütler and Schlaepfer 2004; MCPFE 2007). This reduction in the amount and related quality of dead wood (Müller and Bütler 2010) has significant implications for its various functions. European lists of endangered species are often dominated by species depending on dead wood (Grove et al. 2002). For Germany, $28 \%$ of the saproxylic beetle species are listed as threatened or regionally extinct (Seibold et al. 2014). Owing to its significance for ecosystem functioning, CWD has been recognized as an indicator of ecological sustainable forest management (MCPFE 2003). Therefore increasing efforts have been undertaken to manage CWD as a habitat component and $\mathrm{C}$ store in forest ecosystems. However, to manage this pool, a basic understanding of patterns and rates of dead wood decomposition in different forests is crucial. Further, for the assessment of $\mathrm{C}$ stocks in dead wood as part of National Greenhouse Gas inventories, detailed information on $\mathrm{C}$ stored in dead wood of different species and their relationship with different decay stages (which are typically captured in inventories) is necessary. So far this knowledge is incomplete and mainly based on expert opinions (Meyer et al. 2003; Rock et al. 2008; Zell et al. 2009). In addition, information on residence times of CWD in different decay classes would be very helpful to forecast its dynamics and to calculate the input and output of different decay stages in order to conserve specific habitats of dead wood dependent species (Kruys et al. 2002; Ranius et al. 2003).

Dynamics of CWD are determined by the input through tree mortality and the output through the decomposition process. The decomposition process is characterised by a decrease in dimension and mass and concomitant changes in biological, physical, and chemical properties. The main process of dead wood decomposition is the loss of organic material through respiration. In addition, its fragmentation through biological activity (in particular by insects) and physical processes can also be important. With ongoing decomposition and decreasing physical stability of CWD, fragmentation increases in importance (Harmon et al. 1986). However, leaching of soluble matter (including C) from CWD logs is of minor importance for mass loss (Spears et al. 2003; Kahl et al. 2012). The specific influence of selected environmental variables such as wood moisture and temperature on CWD decomposition can be explored in detail via lab incubation (see Herrmann and Bauhus 2012). However, to capture the complex interplay of processes responsible for decomposition in forests, longterm field measurements are necessary.

The decomposition rate of CWD is mainly dependent on climatic (wood temperature, wood moisture) and substrate specific variables (tree species, decay stage, diameter), where tree species influences chemical and physical wood properties and the decomposer community (Mackensen et al. 2003; Kahl 2008). Up to now it is not clear whether climatic or substrate specific variables are more important for the decomposition process (see also Cornwell et al. 2009; Freschet et al. 2011). Recent results indicated that climatic variables are likely to be more important for (short term) CWD mineralization than substrate specific variables (Herrmann and Bauhus 2012). However, both factors also clearly interact and must therefore be considered jointly (Herrmann and Bauhus 2012). Here, we analysed the influence of these factors on the field decomposition rate of Fagus sylvatica L., Picea abies (L.) Karst. and Pinus sylvestris L. along a climatic/altitudinal gradient (temperature, precipitation) using a chronosequence approach based on known ages of CWD logs. In addition, the influence of log dimension was assessed by analysing CWD pieces of different initial diameters (in three diameter classes, i.e., $>10$ $20 \mathrm{~cm},>20-40 \mathrm{~cm},>40 \mathrm{~cm}$ ).

Our specific research questions were:

1. How do decomposition rates differ between the three tree species Fagus sylvatica (hardwood), Picea abies and Pinus sylvestris (softwoods)?

2. To what extent can the variation in mass and carbon remaining in CWD be explained by tree species, log dimension, wood chemistry (nutrients, lignin) and microclimatic conditions?

In addition, we tested if it was possible to determine the dry density of CWD logs with the drill resistance method.

\section{Methods}

\section{Study sites}

For the chronosequence approach that relates mass (i.e., wood density $\times$ volume) to the age of CWD, logs were sampled at sites where the previous stand had been wind-thrown and where no or only little salvage logging had taken place. Thus we could be certain about the period that logs had undergone decomposition. The study sites were mainly located in southern Germany, except for the oldest site that was situated in northern Germany (Lower Saxony, near the city of Hannover). All selected sites were hit by severe winter storms in 1999, 1990 and 1972 (Table 1). 
Table 1 Description of the study sites

\begin{tabular}{|c|c|c|c|c|c|}
\hline Site & Year of tree fall & Elevation $^{\text {a }}$ ( $m$ a.s.l. $)$ & Soil type ${ }^{b}$ & $\begin{array}{l}\text { Average temperature } \\
\text { per year }\left({ }^{\circ} \mathrm{C}\right)\end{array}$ & $\begin{array}{l}\text { Precipitation }^{c} \\
\text { (mm per year) }\end{array}$ \\
\hline Forêt de Ha-guenau (FdH) & 1999 & $150-170$ & Gleyic Cambisol & 10.98 & 645 \\
\hline Bienwald (Biw) & 1999 & $100-130$ & Cambisol & 10.0 & $680-700$ \\
\hline Röttlerwald (Roe) & 1999 & $510-590$ & Luvisol and Cambisol & $9-10$ & $900-1080$ \\
\hline Lotharpfad (Lot) & 1999 & 950 & Podsolic Cambisol & 7.0 & 1700 \\
\hline Hofstatt (Hof) & 1990 & $320-340$ & Luvisol & 8.8 & 800 \\
\hline Silbersandgrube (Sig) & 1990 & 550 & Luvisol & 7.8 & 665 \\
\hline Kiekenbruch (Kib) & 1972 & 70 & Podsolic Cambisol & 8.5 & 657 \\
\hline
\end{tabular}



\section{Sampling design}

Downed CWD of F. sylvatica, P. abies and P. sylvestris from three different years of tree fall (1972 (except for beech), 1990 and 1999) was sampled in three different initial diameter classes $(>10-\leq 20 \mathrm{~cm},>20-\leq 40 \mathrm{~cm}$, $>40 \mathrm{~cm}$ ). Samples originating from wind throws in 1999 were collected along an altitudinal gradient from the Rhine valley up to the top of the black forest (Table 2). This represents a climatic gradient with regard to temperature and precipitation (see Table 1). Unfortunately, no pine CWD was found at the highest elevation.

In our design, site was not independent from year since tree fall. Generally we sampled at least 5 replicates for each combination of species, site, and diameter. Where clearly different diameter classes were present along the length of a single log, we selected in some cases several sample-points at a minimum distance of $2 \mathrm{~m}$, where discs were extracted. Discs were approximately $10 \mathrm{~cm}$ thick. On average, we extracted 2.5 sample discs per log. These samples were treated as separate samples, because the variations in wood density from one $\log$ and within the same decay class were comparable to the variations within the same decay class when collected from a large population of logs in the field (see also Müller-Using and Bartsch 2009). Separate samples from the same log can also differ considerably in composition of the microflora, as has been shown by others (Shigo 1986; Schwarze et al. 1999). In addition, our preliminary analysis showed that samples from the same log

Table 2 Year of storm event (i.e., decomposition time) and elevation for the 7 study sites

\begin{tabular}{llll}
\hline \multirow{2}{*}{$\begin{array}{l}\text { Year of } \\
\text { storm event }\end{array}$} & \multicolumn{2}{l}{ Elevation (m a.s.l.) } & \\
\cline { 2 - 3 } & 100 & 600 & 900 \\
\hline 1999 & Biw (spruce, pine), & $\begin{array}{l}\text { Roe (beech, } \\
\text { spruce, pine) }\end{array}$ & Lot (beech, spruce) \\
& FdH (beech) & $\begin{array}{l}\text { Hof (beech), Sig } \\
\text { (spruce, pine) }\end{array}$ \\
1990 & &
\end{tabular}

Biw Bienwald, FdH Forêt de Haguenau, Roe Röttlerwald, Lot Lotharpfad, Hof Hofstatt, Sig Silbersandgrube, Kib Kiekenbruch were not autocorrelated according to the Durbin Watson-Test (DW = 1.7).

Decay class was assessed for each log and measurement position according to a 4 stage classification system (Albrecht 1991 for P. abies and P. sylvestris), modified for F. sylvatica by Müller-Using and Bartsch (2009). Based on the decay class and the associated known wood densities, log volumes assessed in field inventories can be converted into CWD mass and C content (Grove et al. 2009). However, because the internal log condition may not be represented by a visual decay classification (Meyer 1999), large errors for assessed C pools can result. Therefore, we also assessed the internal density of logs with the drill resistance method (Kahl et al. 2009). At each point, where log diameter was measured, two drill resistance measurements were conducted, one horizontally and one vertically. In general, at least one stem disc per tree, representing the dominating decay class, was cut with a chainsaw at a drill resistance measurement position for further calibration and analysis. If more than one diameter or decay class was analysed per log, the number of extracted discs increased accordingly. At the site 'Lot' no discs could be removed for most beech logs, as their position was very close to a hiking trail. In this case samples were taken with a wood corer (according to the method applied above).

\section{Density assessment}

Density was assessed gravimetrically and via drill resistance measurements using the Resistograph 3450S (RINNTECH, Heidelberg, Germany) with a resolution of $0.01 \mathrm{~mm}$ and a maximum drilling depth of $44 \mathrm{~cm}$ (for further details see Kahl at al. 2009).

To determine density of wood samples gravimetrically, wooden bars were cut with a band saw along the drill resistance measurement lines for each sampled stem disc. These were further cut into small cubes (about $2 \mathrm{~cm}$ thick) and dried in a fan-forced oven at $105^{\circ} \mathrm{C}$ until constant weight was achieved. Dry density was measured for each cube (without further sample preparation) via the 
water displacement method and related to the drill resistance value for calibration.

\section{Log fragmentation assessment}

Log fragmentation was assessed over one year for log segments of intermediate diameters $(>20-40 \mathrm{~cm})$ of $F$. sylvatica, P. abies and P. sylvestris after 8 and 18 years of decomposition (representing initial and advanced decay stages), with three replicates per species and year. Nylon fabric $(1 \mathrm{~mm} \times 1 \mathrm{~mm}$ mesh, ca. $180 \mathrm{~cm}$ length and about $120 \mathrm{~cm}$ width) was placed underneath each log and metal pegs were used to hold up the material. After one year, the material that had fallen onto the nylon mesh was collected and quantified.

\section{Chemical analysis}

Following density assessment, a subset of all samples with a total of 3 replicates per species, decay stage and diameter class was ground and analysed for $\mathrm{C}$ concentration. $\mathrm{C}$ concentration was determined by combustion at $950{ }^{\circ} \mathrm{C}$ with a Leco Truspec ${ }^{\text {Tx }} \mathrm{CN}$ analyser (St. Joseph, MI, USA). Wood cores were taken from intact wood (1 sample per diameter class per species and site, except for the sites 'Biw', 'Lot' and ' $\mathrm{FdH}$ ') to estimate initial nutrient concentrations. $\mathrm{N}$ concentration was determined according to the method described above for $\mathrm{C}$ concentration. Concentrations of $\mathrm{P}, \mathrm{S}, \mathrm{Ca}, \mathrm{K}, \mathrm{Mg}, \mathrm{Na}, \mathrm{Al}, \mathrm{Fe}$, and $\mathrm{Mn}$ were analysed with Inductively Coupled Plasma-Optical Emission Spectroscopy (ICP-OES) (Spectro, Kleve, Germany), following $\mathrm{HNO}_{3}$ digestion in pressure chambers. Lignin concentration was measured according to the methods proposed by TAPPI (1976) and Effland (1977).

\section{Data analysis}

To calculate decomposition constants $(k)$ based on mass loss, mean dry density from gravimetric density assessment was used if available. Otherwise we used mean dry density based on drill resistance. For each measurement position, the volume of the stem disc represented by this position was calculated based on formula 1 :

$$
V=L * \pi *\left(\frac{d}{2}\right)^{2}
$$

We determined the $k$ values of each individual log or measurement position based on the single negative exponential decay model (Olson 1963):

$$
k=\frac{-\ln \left(\frac{M(t)}{M(0)}\right)}{t}
$$

Here $M(t)$ is the mass (g) remaining at time $\mathrm{t}$ (year) and $M(0)$ is the original mass $(\mathrm{g})$ at time 0 and $k$ is the decomposition rate constant $\left(\right.$ year $\left.^{-1}\right)$. The average $k$ value for each species and size class was then calculated on the basis of these individual $k$ values.

The time when $50 \%$ of the original mass would have been decomposed was calculated by:

$$
t_{0.5}=\frac{0.693}{k}
$$

To model CWD decomposition, exponential decay functions, which assume a homogeneous substrate that decays at a constant rate, have been used in the majority of cases (Mackensen et al. 2003). This may be an oversimplification of the complex processes occurring during dead wood decomposition. Recent modelling approaches have also considered the different wood constituents such extractives, cellulose or lignin, which undergo, owing to their chemical resistance, different decomposition dynamics (Tuomi et al. 2011). However, we did not employ such model, because the temporal resolution of our data would not have permitted a robust fitting of the decomposition process using a model with many parameters. To facilitate comparison of results with that of other studies, we fitted the exponential decay functions for all tree species.

Original dry mass of undecayed wood of the three tree species was calculated based on original diameter and dry density values from literature studies (Trendelenburg and Mayer-Wegelin 1964). Reference values for dry density $\left(\mathrm{g} \cdot \mathrm{cm}^{-3}\right)$ were: $F$. sylvatica: Lot: 0.65 , all other sites: 0.68; P. abies: Lot: 0.4, Kib: 0.46, all other sites: 0.43 ; P. sylvestris: $\mathrm{Kib}>40 \mathrm{~cm}$ : 0.45 , all other sites and diameter classes: 0.49. Different values reflect site (i.e., climatic) differences and variation along stem height (pine), as observed by Trendelenburg and Mayer-Wegelin (1964). Additionally, wood cores (three replicates) were taken from undecomposed wood from the different sites (except for Lot), tree species and diameter (stratified as $>30 \mathrm{~cm}$ and $<30 \mathrm{~cm}$, and $30 \mathrm{~cm}$ for pine at Roe) to confirm that density values from the literature were appropriate.

If the original diameter was different from the current diameter (i.e., bark and/or (sap) wood was already decomposed), it was reconstructed based on the thickness of intact parts on the same log or adjacent logs.

\section{Statistical analysis}

Statistical analyses were conducted using SPSS Statistics 17.0 (SPSS Inc., Chicago, IL, USA) and R (R Development Core Team). All significance testing was done with $p<0.05$. The analysis for even distribution of the residuals was conducted graphically via normal qq-plot and scatter plot (residuals vs. predicted values; and vs. fitted values (linear regression model)), as well as via Kolmogorov-Smirnov test (Dormann and Kühn 2009). 
A transformation (usually $\ln$ ) was conducted, if residuals were not evenly distributed.

A two-way ANOVA was conducted to test for significant differences in wood density and in $\mathrm{C}$ content between the three species as well as between the different decay stages. A one-way ANOVA followed by Fisher's LSD or Dunnett-T3 post-hoc test, if variances were not homogenous, was conducted to further analyse possible differences in 1) $k$ (ln-transformed) between the three species as well as between the different diameter classes at the species level, 2) mass remaining at the species level for each period, beginning at $t_{0}$, for which logs had undergone decomposition, 3) wood density between species for each decay stage and to compare the average dry density of the different decay stages for each species and 4) $\mathrm{C}$ concentration between the different decay stages of each species. In the case of P. Sylvestris (only one sample in decay stage 4 , a two-sample $t$-test was applied for comparison between decay stages.

The influence of substrate specific, climatic and environmental variables on the mass of logs remaining after different periods of decomposition in the field was analysed based on a linear mixed-effects model. Possible influencing variables were identified using a Spearman rho correlation matrix. The climatic variables (temperature and precipitation) were analysed for collinearity and centered for further use in the model. The residuals were further analysed for even distribution graphically via box-cox transformation. To decide if a model is better than a previous model, we used the explained variation $\left(r^{2}\right)$ and the AIC as $1^{\text {st }}$ and $2^{\text {nd }}$ criteria. Eta squared was used as an effect size measure.

To assess the residence time (based on Kruys et al. 2002), in total and for each decay stage, the average dry density $\left(\mathrm{g} \cdot \mathrm{cm}^{-3}\right)$ and the average decomposition time (years) per decay stage were calculated from the whole dataset in a first step. For further calculations, each decay stage was defined as the interval between the midpoints of dry densities of decay classes (e.g., 0.5-1.49 for decay stage 1). Afterwards a dry density value was assigned for each decay stage interval based on the exponential relationship between decay stage and average dry density. In the same way, the decomposition time was assigned, which was calculated based on the exponential relationship between average dry density and average decomposition time. Finally the residence time per decay stage was defined as the decomposition time at the upper bound of each decay stage.

\section{Results}

\section{Drill resistance measurements}

Up to $77 \%$ of the variation in wood density could be explained with drill resistance for beech (Fig. 1). For spruce and pine, only $58 \%$ and $50 \%$ of the variation in density were explained with drill resistance, respectively.

\section{Decomposition rates $(k)$ and mass loss}

The average $k$ value of $F$. sylvatica $\left(0.054\right.$ year $^{-1} ; 95 \%$ CI: 0.048-0.059 year $\left.^{-1}\right)$ was significantly different from the one of $P$. abies $\left(0.033 \mathrm{year}^{-1} ; 95 \%\right.$ CI: 0.03-0.035 year $\left.{ }^{-1}\right)$ and $P$. sylvestris $\left(0.032\right.$ year $^{-1}$; $95 \%$ CI: $0.028-0.035$ year $\left.^{-1}\right)$ across all sites and diameter classes $(p<0.001)$ (Table 3). The two conifer species were not significantly different from each other. The corresponding average diameters of logs were $34.8(\mathrm{SD} \pm 14.8) \mathrm{cm}$ for F. sylvatica, $33.9(\mathrm{SD} \pm 13.9) \mathrm{cm}$ for $P$. abies and $32.2(\mathrm{SD} \pm 12.1) \mathrm{cm}$ for $P$. sylvestris indicating that the effects of species were not biased through differences in log dimensions between species. The time until $50 \%$ of the initial mass was decomposed was 13 years for F. sylvatica, 21 years for $P$. abies and 22 years for $P$. sylvestris. The average $k$ values until 18 years for $P$. abies and $P$. sylvestris were 0.033 year $^{-1}$; $95 \%$ CI: 0.031-0.036 year $^{-1}$ and 0.034 year $^{-1}$; $95 \%$ CI: $0.03-0.037$ year $^{-1}$, respectively.

Owing to different decomposition rates, the patterns of mass remaining differed accordingly between the species (Fig. 2). Whereas the average mass remaining in $P$. sylvestris CWD was similar to that of $P$. abies until 18 years of decomposition (about $59 \%$ each (SD \pm 12 , resp. $11 \%$; $P$. abies)), it was considerably higher at year 36 (P. sylvestris: $46 \%$ (SD \pm 15$),$ P. abies: $39 \%(\mathrm{SD} \pm 18)$ ). At this time, nearly all sapwood of $P$. sylvestris logs was decomposed and heartwood started to decompose. Average mass remaining decreased with increasing decomposition time in all species $(p<0.05$, Fig. 2$)$.

With increasing diameter class, decomposition rates decreased significantly in all species, except between the diameter classes $<20 \mathrm{~cm}$ and $>20-40 \mathrm{~cm}$ for $P$. abies (Table 3).

\section{Prediction of mass remaining}

About $74 \%$ of the variation in mass remaining could be explained by decomposition time (27\%), tree species (11\%), diameter (17\%), the interactive effects between tree species and diameter (4\%) as well as between decomposition time and tree species $(3 \%)$ and a random factor with site and tree $(9.5 \%)$, whereas temperature explained only $2 \%$ of the variation (Table 4 ). If we subtract the random factor, which cannot be predicted, $64 \%$ of the variation in mass remaining may be predicted for the tree species investigated here.

If initial nutrient concentrations were considered as additional independent variables, a slight model improvement was achieved, when the concentration of manganese was included. Based on a reduced data set ( $n=172$ instead of $n=287$ ), an additional $1 \%$ of the total variance could be explained. 


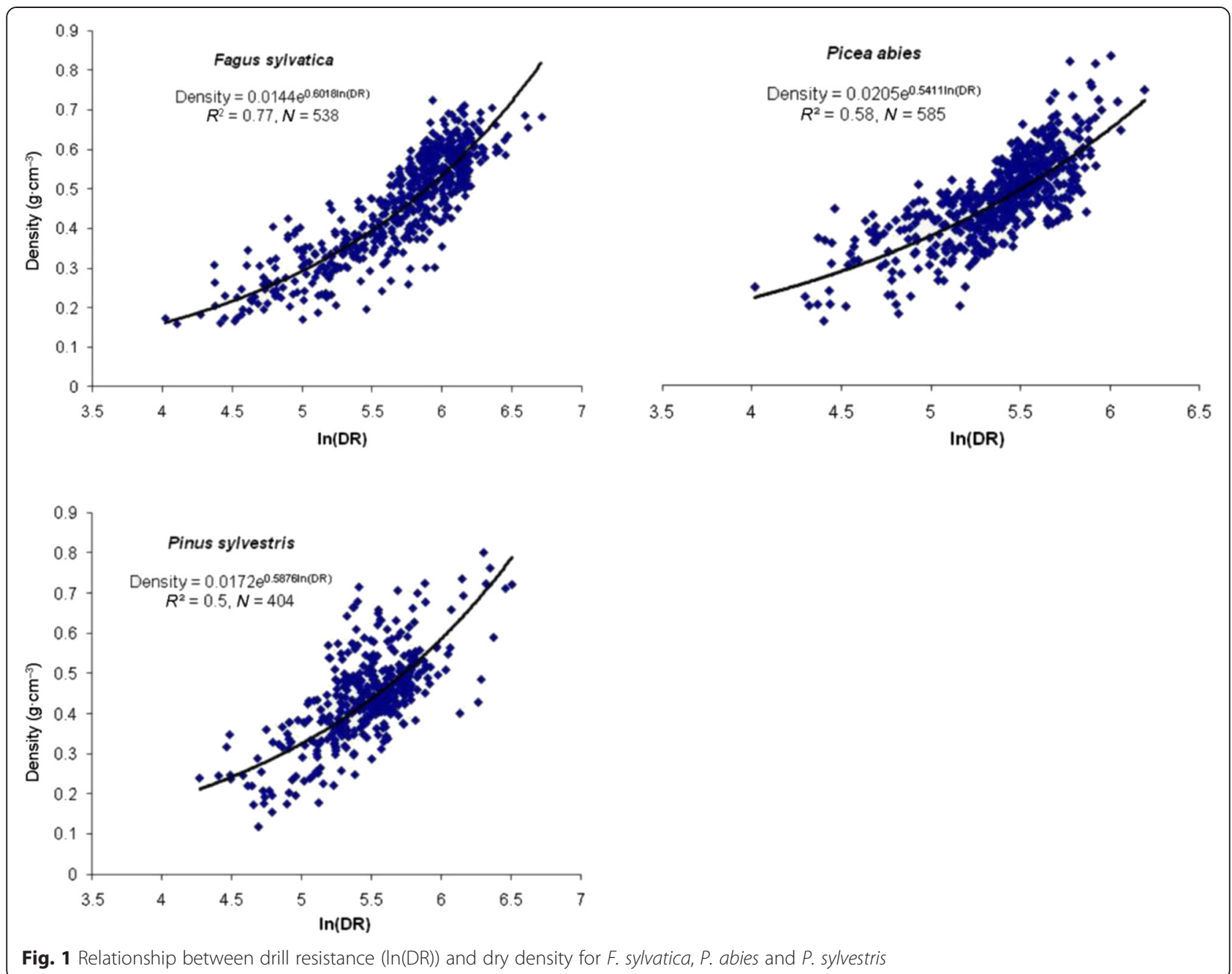

\section{Log fragmentation}

The amount of fragmented material differed between tree species and age of logs, but in relation to total mass it was very low (Table 5 ). The maximum value was $1.8 \%$ per annum for one P. abies $\log$ (Table 5). For F. sylvatica and $P$. abies, bark fragmentation dominated after the first 8 years of decomposition. In $P$. sylvestris, only a minor amount of bark fragmentation and no wood fragmentation occurred during this period of time. In older logs of F. sylvatica and $P$. abies (18 years), fragmented material originated mostly from wood in logs and was much higher in the former than the latter species. For P. sylvestris, bark fragmentation dominated in older logs. Fragmentation was very patchy between individual logs and often occurred as a single event, as indicated by the high standard deviation. However, when fragmentation is related to the decomposition rate, the actual contributions are considerable. When compared to the total $k$ value for first 18 years of decomposition, fragmentation over one year accounted for $27 \%$ for beech, $14 \%$ for spruce and $30 \%$ for pine, respectively.

Table 3 Annual decomposition constants k for different diameter classesin Fagus sylvatica, Picea abies and Pinus sylvestris

\begin{tabular}{|c|c|c|c|c|}
\hline \multirow[t]{2}{*}{ Species } & \multicolumn{3}{|c|}{ Diameter class $(\mathrm{cm})$} & \multirow[t]{2}{*}{ Combined } \\
\hline & $<20$ & $20-40$ & $>40$ & \\
\hline F. sylvatica $(n=96)$ & $0.078(0.027)^{a}$ & $0.055(0.027)^{b}$ & $0.035(0.015)^{c}$ & $0.054(0.028)$ \\
\hline P. abies $(n=107)$ & $0.034(0.011)^{a}$ & $0.036(0.012)^{a}$ & $0.027(0.013)^{b}$ & $0.033(0.013)$ \\
\hline P. sylvestris $(n=83)$ & $0.050(0.015)^{a}$ & $0.030(0.01)^{b}$ & $0.021(0.01)^{c}$ & $0.032(0.015)$ \\
\hline
\end{tabular}

Values are means with standard deviation in parentheses. Different letters indicate significant differences between diameter classes $(p<0.05)$ 




\section{Residence time per decay class}

The residence time per decay class increased with decay class (i.e., higher degree of decomposition). This increase was most pronounced in pine and least pronounced in beech (Table 6). In addition, with decreasing decomposition rate from $F$. sylvatica to $P$. sylvestris, the proportion of time, relative to the entire decay process, that logs stayed in the first decay stage became shorter, whereas the time in the last decay stage increased.

\section{Wood density, carbon content and decay stage}

Average dry density values differed significantly between species and decay stages. Specifically, average dry densities were significantly different between $F$. sylvatica, $P$. abies and $P$. sylvestris for decay stage 2 $(p<0.001)$. For decay stage 3 , dry density of $F$. sylvatica was significantly different from those of $P$. abies and $P$. sylvestris $(p<0.001$ and $p<0.01)$, which were similar to each other. No significant differences between species were found for decay stage 4 .

Average dry density decreased with increasing decay stage in all species $(p<0.001$; Fig. 3$)$.

The decrease in density was highest from decay stage 2 to 3 and the density variation was highest in decay stage 3 for all three species, but in particular for F. sylvatica. In dead wood of F. sylvatica, the decrease in density was not significant between decay stages 3 and 4 . In contrast, a significant decrease between decay stages 3 and 4 was found for $P$. abies $(p<0.05)$. For $P$. sylvestris there was only one value in decay stage 4 .

Similar to dry density, carbon concentration was significantly higher for $F$. sylvatica, compared to $P$. abies and $P$. sylvestris, which were not different from each other (Table 7). With advancing decomposition and decreasing dry density, an increase in $C$ concentration was observed for all three species (except between decay stages 3 and 4 for beech and spruce). C concentration differed significantly between decay stages 1 and 2, as well as 3 for F. sylvatica and P. abies. For P. abies, decay stage 1 was significantly different also from decay stage 4 , while decay stages 1 and 2 were significantly different from decay stage 3 for P. sylvestris (Table 7).

The effect of decay stage on carbon (C) density was dependent on species $(p=0.000)$. The pattern of $C$ density and decay stage followed the pattern of wood density and decay stage closely (Table 7 and Fig. 3).

\section{Discussion}

\section{Decomposition rates $(k)$ and mass loss}

To our knowledge, this is the first study that systematically assessed CWD decomposition rates and dynamics of Fagus sylvatica, Picea abies and Pinus sylvestris across different sites and diameter classes in Central Europe. Average $k$ values of $F$. sylvatica were significantly higher than those of $P$. abies and P. sylvestris across all sites and diameter classes.

In other studies, decomposition rates of $F$. sylvatica varied from 0.056 year $^{-1}$ (Kahl 2008) to 0.089 year $^{-1}$ 
Table 4 Linear mixed-effects model (ANOVA table) to predict the remaining massof Fagus sylvatica, Picea abies and Pinus sylvestris

\begin{tabular}{llllll}
\hline Source & Sum of Squares & df & $F$ & Sig. & Eta squared \\
\hline Decomp. time & 12162.2 & 1 & 129.449 & 0.000 & 27.06 \\
Tree species & 5058.7 & 2 & 12.768 & 0.000 & 11.26 \\
Diameter & 7655.1 & 1 & 97.979 & 0.000 & 17.03 \\
Temperature & 789.4 & 1 & 7.273 & 0.009 & 0.003 \\
Decomp. time $\times$ Species & 1405 & 2 & 6.066 & 1.76 \\
Species $\times$ Diameter & 1873.8 & 2 & 10.8 & 0.000 & 3.13 \\
\hline
\end{tabular}

Conditional $R$-squared: 0.739 (Marginal $R^{2}: 0.644$ )

(Müller-Using and Bartsch 2009), with intermediate values of $0.06-0.075$ year $^{-1}$ (Christensen et al. 2005; based on 86 European beech forest reserves). In comparison to these findings, our $k$ value for beech of 0.054 year $^{-1}(\mathrm{SD} \pm 0.028,52 \%)$ is within the range of variation and very similar to the estimate by Kahl (2008).

The difference between $k$ values of beech may be attributed to the uncertainty over the cause of death, as observed by Kahl (2008). In that study, a $k$ value of 0.075 year $^{-1}(\mathrm{SD} \pm 0.034)$ for logs that died naturally (infected by Fomes fomentarius prior to death) and a $k$ value of 0.025 year $^{-1}(\mathrm{SD} \pm 0.012)$ for wind thrown logs was calculated (mean diameter $>40 \mathrm{~cm}$ ). This indicates that decomposition had advanced already in trees affected by $F$. fomentarius before they died or fell. We calculated a $k$ value of 0.035 year $^{-1}(\mathrm{SD} \pm 0.015)$ for the diameter class $>40 \mathrm{~cm}$; which is similar to the estimate by Kahl (2008). Most of the trees died "naturally" due to F. fomentarius in the study by Müller-Using and Bartsch (2009), which may mainly explain the high $k$ value in that study. It can be assumed that most logs investigated in our study originated from trees that were still vital compared to trees that died "naturally". In freshly fallen logs, colonization by (cord-forming) basidiomycetes differs from logs that have already been affected by fungi before they fell and wood can be expected to decay slower (Boddy and Heilmann-Clausen 2008). Further, tissues that have died "naturally" may be predisposed to microbial colonization, whereas artificially detached living tissues (i.e., due to wind breakage) may maintain metabolic activities against decomposers (see Yin 1999). In addition, different $k$ values might result (to some extent) from different tree diameters in other studies. Colonization by (cord-forming) basidiomycetes seems to progress slower in large diameter logs (Boddy and Heilmann-Clausen 2008). Although this is not supported by the results of this study, different site, i.e., microclimatic conditions might further lead to an increase or decrease in $k$ values, for example through canopy removal (Hagemann et al. 2010; Forrester et al. 2012). Managed forests may also harbor a lower diversity of wood decaying fungi, which may lead to different decay rates (Stenlid et al. 2008; Purahong et al. 2014a, b). With regard to the origin of dead wood and its diameters, our data are likely more representative of managed forests rather than strict reserves.

The decomposition rate of 0.033 year $^{-1}(\mathrm{SD} \pm 0.013$ $39 \%$ ) for P. abies calculated in our study was comparable to $k$ values in other studies (see Rock et al. 2008). In detail, it was in the range of variation of the estimate by Kahl (2003; 0.027 year $\left.^{-1}(\mathrm{SD} \pm 0.023)\right)$ in Central Germany and identical to $k$ values found by Naesset (1999; $k=0.033$ year $^{-1}$; mean diameter: $\left.13 \mathrm{~cm}\right)$ in southeastern Norway. It was also similar to values in European (Shorohova and Kapitsa 2014) and Russian boreal forests (Krankina and Harmon 1995; Krankina et al. 1999; Tarasov and Birdsey 2001; Harmon et al. 2000; Yatskov et al. 2003).

The conditions of the decomposition process in the study by Naesset (1999) were very similar to our situation. Their starting point of the decomposition process was the date of cutting. All logs were free from rot at the time of cutting and the decomposition took place in open areas.

Table 5 Annual fragmentation loss for bark and wood of Fagus sylvatica, Picea abies and Pinus sylvestris

\begin{tabular}{lllll}
\hline Species & CWD age (yrs) & Bark (\% total fragmentation loss) & Wood (\% total fragmentation loss) & Fragmentation (\% total mass) \\
\hline F. sylvatica $(n=6)$ & 8 & $99.6(0.4)$ & $0.4(0.4)$ & $0.27(0.37)$ \\
& 18 & $28.5(27.2)$ & $71.5(27.2)$ & $0.02(0.01)$ \\
P. abies $(n=6)$ & 8 & $98.3(3)$ & $1.7(3)$ & $0.13(0.22)$ \\
& 18 & 0 & 100 & $0.65(1.02)$ \\
P. sylvestris $(n=6)$ & 8 & 100 & 0 & $0.01(0.01)$ \\
& 18 & $73.8(18.8)$ & $26.2(18.8)$ & $0.18(0.20)$ \\
\hline
\end{tabular}

Values are means with standard deviation in parentheses 
Table 6 Absolute and relative residence times per decay stage for CWD logs of Fagus sylvatica, Picea abies and Pinus sylvestris

\begin{tabular}{|c|c|c|c|c|c|c|}
\hline \multirow{3}{*}{$\begin{array}{l}\text { Decay } \\
\text { stage }\end{array}$} & \multicolumn{6}{|c|}{ Residence time (Years) } \\
\hline & \multicolumn{2}{|c|}{ Fagus sylvatica } & \multicolumn{2}{|c|}{ Picea abies } & \multicolumn{2}{|c|}{ Pinus sylvestris } \\
\hline & yrs & $\%$ & yrs & $\%$ & yrs & $\%$ \\
\hline 1 & 6.7 & 12.2 & 8.6 & 9.8 & 6 & 6.0 \\
\hline 2 & 10.7 & 19.5 & 15.3 & 17.4 & 14 & 14.0 \\
\hline 3 & 15.8 & 28.8 & 25.3 & 28.8 & 28.3 & 28.4 \\
\hline 4 & 21.6 & 39.4 & 38.5 & 43.9 & 51.5 & 51.6 \\
\hline
\end{tabular}

Relative residence times were calculated as percent of the sum of residence times for each species
Compared to beech, decomposition rates $k$ from the literature are much less variable for spruce. One explanation for this may be that the sensitivity to influencing factors (as cause of death, decomposer community or differences in diameter) is less pronounced in spruce. This may partly be attributable to a higher decay resistance of spruce and more uniform substrate conditions (see also Cornwell et al. 2009; Weedon et al. 2009) when compared to beech.

However, we observed a significant effect of diameter on $k$ values also for spruce. Since all comparable studies in boreal regions were conducted mainly on small diameter trees, the variation between $k$ values should also be small. In our study, the influence of climatic variables on

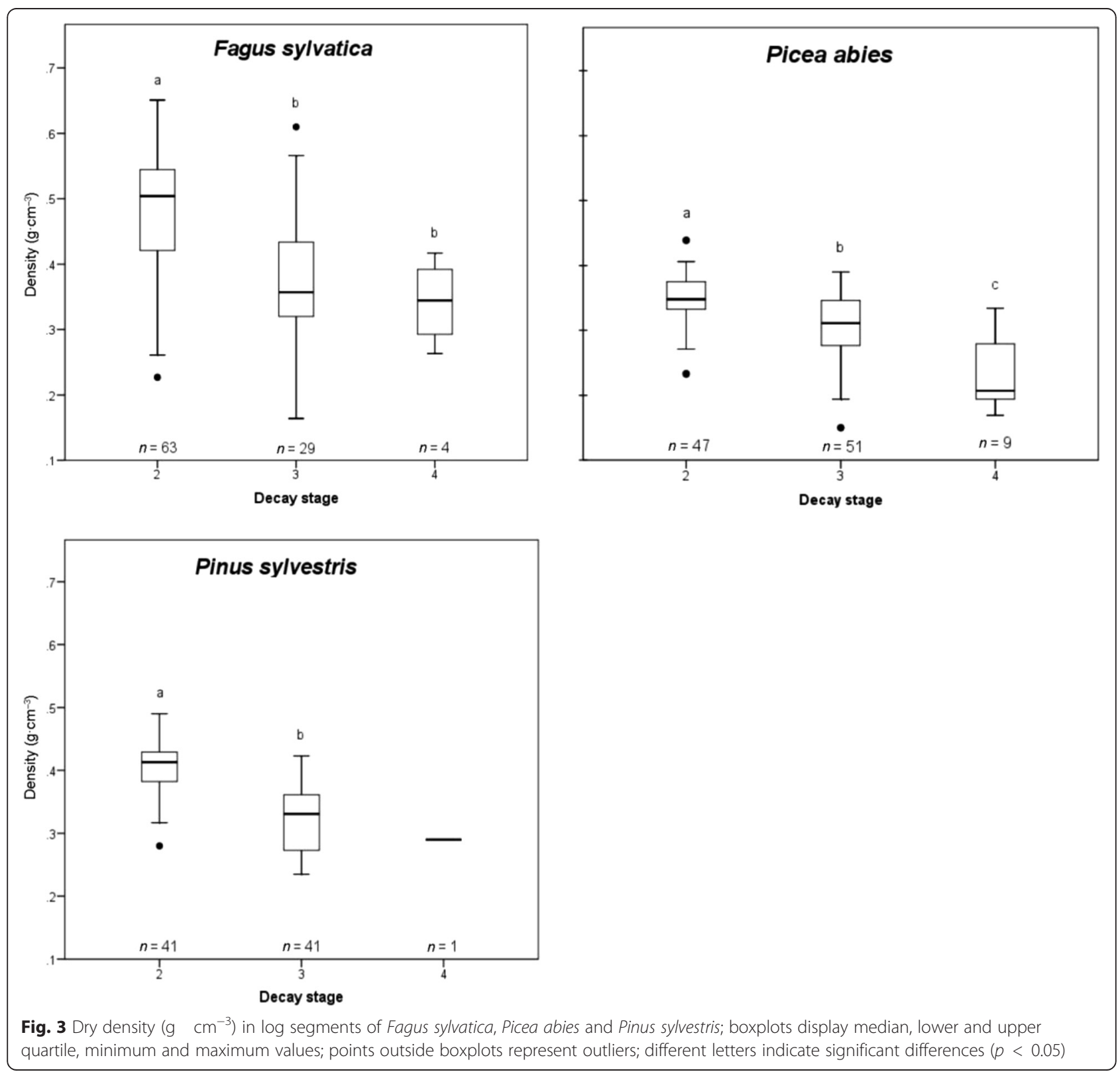


Table 7 Carbon concentrations (\%) and contents $\left(\mathrm{mg} \mathrm{cm}^{-3}\right)$ in relation to decay stage (DS), mean and standard deviation (SD), as well as no. of samples, of log segments of Fagus sylvatica, Picea abies and Pinus sylvestris

\begin{tabular}{|c|c|c|c|c|c|c|c|c|c|c|c|c|c|c|c|}
\hline \multirow[t]{3}{*}{ Species } & & \multicolumn{12}{|c|}{ Decay stage } & \multirow{2}{*}{\multicolumn{2}{|c|}{$p$ value (Anova) }} \\
\hline & & \multicolumn{3}{|l|}{1} & \multicolumn{3}{|l|}{2} & \multicolumn{3}{|l|}{3} & \multicolumn{3}{|l|}{4} & & \\
\hline & & Mean & SD & $\bar{n}$ & Mean & SD & $n$ & Mean & SD & $n$ & Mean & SD & $\bar{n}$ & $\mathrm{DS}$ & Species \\
\hline \multirow[t]{2}{*}{ F. sylvatica ${ }^{a}$} & $\%$ & $46.3^{a}$ & 0.52 & 4 & $47.5^{b}$ & 0.62 & 39 & $47.5^{\mathrm{b}}$ & 0.73 & 22 & $47.4^{\mathrm{ab}}$ & 0.31 & 2 & $<0.05$ & $<0.001$ \\
\hline & $\mathrm{mg} \mathrm{cm}^{-3}$ & $315^{\mathrm{a}}$ & 3.6 & & $238^{\mathrm{b}}$ & 36.8 & & $174^{c}$ & 48.3 & & $161^{c}$ & 52.7 & & & \\
\hline \multirow[t]{2}{*}{ P. abies ${ }^{b}$} & $\%$ & $47^{a}$ & 0.89 & 7 & $49.9^{b}$ & 1.51 & 38 & $50.1^{b}$ & 1.73 & 34 & $49.8^{b}$ & 2.73 & 9 & $<0.01$ & \\
\hline & $\mathrm{mg} \mathrm{c \textrm {cm } ^ { - 3 }}$ & $203^{a}$ & 9.2 & & $170^{\mathrm{b}}$ & 17.4 & & $155^{c}$ & 18.1 & & $117^{c}$ & 34.1 & & & \\
\hline \multirow[t]{2}{*}{ P. sylvestris ${ }^{\text {b }}$} & $\%$ & $48.8^{a}$ & 1.13 & 5 & $49.2^{a}$ & 1.54 & 34 & $50.2^{\mathrm{b}}$ & 1.31 & 31 & 51.4 & & 1 & $<0.05$ & \\
\hline & $\mathrm{mg} \mathrm{cm}^{-3}$ & $235^{\mathrm{a}}$ & 11.4 & & $198^{b}$ & 22.6 & & $162^{c}$ & 28.5 & & $149^{d}$ & & & $<0.01$ & \\
\hline
\end{tabular}

Small letters indicate significant differences between tree species for total C concentration as well as between the different decay stages within each species

the decomposition, also of spruce logs, was low. For example, we found no difference between $k$ values for the sites Kib ('cold and wet') and Sig ('warm and dry'), which may simply reflect different types of climatic limitations for wood decaying fungi when compared to the 'warm and wet' optimum, which was not represented in our design.

Our $k$ value for $P$. sylvestris $\left(0.032\right.$ year $^{-1}$ (SD \pm $0.015,47 \%)$ ) was similar to values found in the boreal forests of Europe (Shorohova and Kapitsa 2014) and Russia (Krankina and Harmon 1995; Harmon et al. 2000; Wirth et al. 2000; Yatskov et al. 2003; see also Rock et al. 2008).

The $k$ value of pine determined in our study was mainly attributable to the loss of sapwood (as heartwood was found to be still largely intact for most logs after 36 years of decomposition time). Hence, if a longer total decomposition period was analysed, the average decomposition constant might be lower than the one we reported here.

Similar to spruce, variation in the decomposition constant $k$ of pine logs was also very low. This may again point to a higher decay resistance and a more uniform decomposition process. In the gymnosperm wood of spruce and pine, there was no highly variable spatial pattern of intact and highly decomposed patches next to each other, as was observed for beech. This observation is in accordance with much higher variation in log respiration rates in dead wood of $F$. sylvatica than in $P$. abies and P. sylvestris (Herrmann and Bauhus 2012).

At a more general level, $k$ values of angiosperm wood are typically higher, on average $77 \%$, than in gymnosperm wood (Weedon et al. 2009). A similar difference was also found by Russell et al. (2014). For comparison, our decomposition rate for beech CWD was about $60 \%$ higher than for spruce and pine.

An estimation of decomposition rates for the federal state of Brandenburg (Northeastern Germany) based on a literature review and expert consultation (Rock et al. 2008) produced $k$ values for $F$. sylvatica, $P$. abies and $P$. sylvestris of 0.067 year $^{-1}, 0.0525$ year $^{-1}$ and 0.0575 year $^{-1}$, respectively. In comparison to our results the estimated $k$ values of $P$. abies and in particular of $P$. sylvestris appear to be too high. The deviations between expert estimates of decay rates and our data underpin the importance of actual measurements. In particular for low decay rates, small absolute errors result in proportionally very large errors when calculating mass loss. For example, using a $k$ value of 0.0525 year $^{-1}$ for Picea abies (Rock et al. 2008), which is 59 \% higher when compared to 0.033 year $^{-1}$ (determined in this study) would shorten the period until $50 \%$ of CWD mass was lost by about $37 \%$ (8 years).

In contrast, the chronosequence approach used in our study may cause an underestimation of $k$, because slowdecaying logs may have a higher probability of being included in the sampling (Kruys et al. 2002; Herrmann and Prescott 2008). However, this problem increases with the decomposition time covered and it is negligible, when the observation period is shorter than the minimum decomposition time for logs. For example, if we assume a) high decomposition rates of $k=0.09$, and b) that logs can still be identified in the field when they contain $20 \%$ of the original mass, no logs should be lost form the sample population before 18 years.

In our study, decomposition rates increased with decreasing diameter class, except for $P$. abies, where the $k$ values between 20 and $40 \mathrm{~cm}$ tended to be slightly higher than in smaller logs $(<20 \mathrm{~cm})$ (Table 4). Lower $k$ values for smaller diameters $(<10 \mathrm{~cm}$ compared to $>25 \mathrm{~cm})$ of $P$. abies were also observed by Naesset (1999), who assumed that it was most likely caused by branches that prevent the logs from soil contact. In our study, the diameters < $20 \mathrm{~cm}$ for $P$. abies were most often sampled in crown sections of the logs, where also soil contact was less often encountered than for $20-40 \mathrm{~cm}$ diameter logs. However, $k$ values commonly decrease with increasing diameter (Graham and Cromack 1982; Stone et al. 1998; Chambers et al. 2000; Mackensen et al. 2003), even if sometimes inconsistent relationships have been reported (see 
Herrmann and Prescott 2008). Hence, where decomposition models for CWD with large variation in dimensions are required, it is advisable to consider log diameter.

We are aware that our assumption of a constant decay rate based on the single negative exponential decay model may be questionable and that there are more sophisticated models, e.g., as applied in the Yasso model (Tuomi et al. 2011). However, our dataset was not sufficient in terms of the variation in decomposition periods of logs to fit the temporal decay dynamics of a more sophisticated model in a robust way. Since there are only very few field experiments that followed mass loss in individual CWD pieces over the long term, the 'real' temporal mass loss pattern is not known. Even if, the mass loss rate of some wood constituents slowed down with increasing time, this may be partially compensated by fragmentation, which was found to be of increasing importance in later decomposition stages (see e.g., Lambert et al. 1980). The mass loss rate may even increase in later stages as observed in the study by Kahl (2008).

\section{Prediction of mass remaining}

A substantial proportion of the variation (64\%) in mass remaining could be predicted by decomposition time, tree species, original log diameter, and their interactive effects, whereas temperature had a very small, and initial nutrient concentrations had almost no influence. The observed influence of manganese concentrations on mass remaining may be explained by the relevance of manganese for lignin degradation by white-rot fungi (Hofrichter et al. 2009).

Similar to our findings, a literature review on CWD decomposition had indicated that tree species had a stronger influence on decomposition and nutrient dynamics than the abiotic environment (Laiho and Prescott 2004). And no effect of lignin or nitrogen concentrations was observed in an attempt to model CWD decay based on data about 300 cases of stem, branch and root woody debris decay from North America (Yin 1999). Also, most of the explained variation of mass remaining in the study by Yatskov et al. (2003) could be attributed to time since death (50\%), $\log$ position (8 \%) and tree species (6\%). However, in some studies, environmental variables did explain a significant proportion of CWD decomposition over time (e.g., Russell et al. 2014). About $80 \%$ of the variance in the decomposition rate constant was explained by a multiple regression model with the factors of tree species, mean diameter, mean temperature in July, sum of precipitation per year and a lag time (Zell et al. 2009).

In contrast to Zell et al. (2009), we observed no significant improvement in our prediction if mean temperature in July instead of mean annual temperature was used in the model.
In a global meta-analysis of wood decomposition rates of angiosperms and gymnosperms, significant relationships between wood traits and decomposition rates were only observed for angiosperms (Weedon et al. 2009). For angiosperms, positive relationships between $k$ and the nutrients $\mathrm{N}$ and $\mathrm{P}$, and a negative relationship between $k$ and $\mathrm{C}: \mathrm{N}$ ratios were found. We suggest that the mass loss of CWD of the species investigated in our study can be sufficiently well predicted for most management and modelling tasks by the factors tree species, time since commencement of decomposition, and log diameter, which can be obtained easily from forest inventories. Predictions will likely become less accurate, when CWD originates from different processes, e.g., when trees also die standing and decay slowly for many years before logs hit the ground, or when the wood decomposition by fungi commences in the living tree (e.g., Kahl 2008). In our field study, most trees were felled as living trees by storms.

In contrast to this field study, about $60 \%$ of the variation in $\mathrm{CO}_{2}$ flux of CWD of the same species was explained by climatic variables (wood moisture and wood temperature) in a lab incubation experiment (Herrmann and Bauhus 2012). In the same study, temperature explained more than $90 \%$ of CWD respiration of individual Fagus sylvatica and Picea abies logs over one year in the field. This comparison shows that scaling up from shortterm CWD respiration measurements to the long-term dynamics of CWD mass loss is difficult, since the combined effects of temperature, moisture, and interactions between substrate quality and microorganisms need to be considered (Herrmann and Bauhus 2008). In order to capture the complex interplay of processes (i.e., respiration, fragmentation) responsible for decomposition in forests, long-term field measurements are necessary.

\section{CWD fragmentation}

The limited study on wood fragmentation indicated that this process may contribute considerably to annual mass loss (max. $30 \%$ of $k$ for pine) although values were lower than in some other studies (e.g., $63 \%$ found by Lambert et al. 1980). Our logs were mainly at the beginning and in the middle of the decomposition process. Fragmentation was found to be of increasing importance with advanced decomposition (Harmon et al. 1986; MüllerUsing and Bartsch 2009) as well as in higher elevations (Lambert et al. 1980). However, our study also showed that fragmentation was highly variable within and between logs, and that single events, such as activities of animals searching for food in the logs, may contribute substantially to mass loss.

Measuring fragmentation over the course of only one year was certainly not sufficient to assess the significance 
of this process in the medium to long-term. This would deserve a separate study. However, it would be very difficult to include fragmentation in models predicting $\mathrm{CO}_{2}$ release from CWD decomposition, since a large proportion of the material lost from CWD through fragmentation is simply transferred to a different pool, the litter layer. And we have no information on the decomposition rate of fragmented wood in the litter layer.

\section{Drill resistance measurements}

In a study that used a similar measurement device, $65 \%$ of the variation in wood density of $P$. abies could be explained by drill resistance (Kahl et al. 2009). The potential to determine wood density in a large number of samples in a short period of time may compensate for the lack of precision for individual pieces in large inventories. In addition, determining drill resistance may be the only form to collect data on wood density in strict forest reserves, where the collection of stem discs is not permitted.

\section{Predicting carbon density in CWD}

The loss of mass and thus carbon in CWD is a continuous process. Using distinct decay stages based on visual assessment of logs can be a useful approach to capture the variation in CWD mass and $C$ density in forest inventories. However, the usefulness of this approach depends on how distinct decay stages differ in wood density and $\mathrm{C}$ concentration.

Here, we observed a high variation in CWD density within decay classes and hence only few significant differences between adjacent decay classes within a given species. Density variation was particularly high for $F$. sylvatica logs in decay stages 2 and 3 . This might suggest, among other things, that decay stages 2 and 3 were most difficult to distinguish by the visual classification system. In some cases, decomposition was found to be more (or less) advanced than 'suggested' by the tree surface (i.e., bark or sapwood condition). This could be the result of case hardening (drying out of the outer sapwood) as decomposition took mostly place in open areas (see also Yin 1999). In addition, decomposition of $F$. sylvatica logs was spatially highly variable. Intact and decomposed patches (with different densities) separated by demarcation lines composed of melanin, which is characteristic of white rot fungi (see also Schwarze et al. 1999; Kahl 2008), were found in direct proximity within the same tree disc. Owing to such patterns of log colonization by fungi, density variation may initially increase with decomposition. For example, an increase in density variation with progressing decomposition, with the maximum in decay stage 3 and a decline towards decay stage 5 , was also observed by Yatskov et al. (2003).
The absence of distinct differences in wood density between decay classes has also been observed in other studies. Little change (respectively an overlap) in density between the two least (1 and 2) and most advanced (4 and 5) decay classes has been found also in the study by Yatskov et al. (2003). Similar to our results, no significant difference in density of decay stages 3 and 4 of $F$. sylvatica were also found by Müller-Using and Bartsch (2009). One main characteristic of log sections in decay stage 4 in our study was the close proximity of highly decomposed material to areas of relatively intact wood. Since the maximum decomposition time for woody debris of $F$. sylvatica in our study was about 16 years, decay stage 4 comprised mainly log segments with a diameter $<20 \mathrm{~cm}$. Hence, our data may not be representative for larger diameter CWD of beech.

Wood densities for the different tree species converged for advanced decay stages, which is in accordance with other studies (Yatskov et al. 2003). We found no significant differences between species for CWD densities in decay stage 4.

The increase in $\mathrm{C}$ concentration with advancing decomposition observed in our study was also found by Müller-Using and Bartsch (2007) for beech. It suggests an increase of lignin and a decrease of cellulose, as lignin has a higher proportion of $\mathrm{C}$ than cellulose. The increase in $\mathrm{C}$ concentration cannot be explained by a decrease of minerals in relation to C. Similar to our results, $\mathrm{C}$ concentrations were lower for angiosperm CWD when compared to gymnosperm CWD in a study that analysed C concentrations of 60 tree species (Harmon et al. 2013). Unlike our results, a decrease in $C$ concentration with increasing decay class was observed for angiosperm CWD in that study. In contrast to $\mathrm{C}$ concentration, $\mathrm{C}$ content was highest for beech, followed by pine and spruce. This can be explained by the higher density of sound wood.

The pattern of $\mathrm{C}$ density $\left(\mathrm{mgC} \cdot \mathrm{cm}^{-3}\right)$ and decay stage was similar to that of wood density and decay stage. $\mathrm{C}$ density decreased parallel with density and mass loss, as has been found by others (Müller-Using 2005). Carbon density in CWD converged across species with increasing decay (similar to the relationship between density and decay stage). Hence for highly decayed logs, for which it may also be difficult to determine the species origin, one common wood and $\mathrm{C}$ density may be assumed.

To assess $C$ in CWD from inventories that record decay stage, our values of dry wood and C density per species and decay stage could be used for calculation purposes. However, the actual assessment of $\mathrm{C}$ concentration in inventories appears to be meaningful only for beech, where the difference between the measured $\mathrm{C}$ concentration and the default value of $50 \%$ was $3.4 \%-4.6 \%$. 


\section{Conclusions}

To our knowledge, this is the first study that assessed the decomposition dynamics of CWD logs of F. sylvatica, $P$. abies and $P$. sylvestris across different sites and diameter classes in central Europe. In comparison to studies at individual sites, sampling of CWD across different sites provides a more robust estimation of decomposition rates because a wider range in climatic conditions and decomposer communities are captured.

Our results indicated that a reasonable prediction of the decomposition of CWD should be possible on the basis of a few easily obtainable parameters, since variables such as diameter and tree species had the greatest influence on mass loss over time. Since the variation in climatic parameters such as average annual temperature and precipitation had only a minor effect on the decomposition process, these variables might be neglected for the prediction of CWD mass loss in this temperature and precipitation range.

The decomposition rates determined in our study, although they may be further refined, provide a basis for the management of CWD. The decomposition constants will allow the development of decomposition models based on information about the input of CWD according to species and diameter. Based on the derived Cdensities per decay stage, $\mathrm{C}$ contents in CWD can be calculated to serve as input to $\mathrm{C}$ accounting of forest ecosystems.

\section{Competing interests}

The authors declare that they have no competing interests.

\section{Authors' contributions}

SH planned and conducted the study including field sampling and analysis and wrote the majority of the manuscript. TK conducted linear mixed effects modelling and contributed to the manuscript. JB conceived and guided the study and co-wrote the manuscript. All authors read and approved the final manuscript.

\section{Acknowledgements}

We are grateful to Renate Nitschke and Germar Csapek, and the many students, who helped in the field and in the lab. We thank Sarah Grimm from Seminar for Statistics ETH Zurich for statistical advice. Oliver Jakoby provided helpful comments to improve the manuscript. This research was funded by a German Science Foundation grant to Jürgen Bauhus (DFG - BA 2821/4-1).

Received: 11 June 2015 Accepted: 13 October 2015

Published online: 24 October 2015

\section{References}

Albrecht L (1991) Die Bedeutung des toten Holzes im Wald. Forstw Cbl 110(1991):106-113

Boddy L, Heilmann-Clausen J (2008) Basidiomycete community development in temperate Angiosperm wood. In: Boddy L, Frankland J, Van West P (eds) Ecology of Saprotrophic Basidiomycetes. Academic, London, pp 211-238

Bütler R, Schlaepfer R (2004) Wie viel Totholz braucht der Wald? Schweiz Z Forstwes 155(2):31-37

Chambers JQ, Higuchi N, Schimel JP, Ferreira LV, Lemack JM (2000) Decomposition and carbon cycling of dead trees in tropical forests of central Amazon. Oecologia 122:380-388
Christensen M, Hahn K, Mountford EP, Odor P, Standovar T, Rozenbergar D, Diaci J, Wijdeven S, Meyer P, Winter S, Vrska T (2005) Dead wood in European beech (Fagus sylvatica) forest reserves. For Ecol Man 210:267-282

Commarmot B, Brändli U-B, Hamort F, Lavnyy V (2013) Inventory of the largest primeval beech forest in Europe. A Swiss-Ukrainian scientific adventure. Swiss Federal Research Institute WSL, Birmensdorf; Ukrainian National Forestry University, L'viv; Carpathian Biosphere Reserve, Rakhiv. p 69

Cornwell WK, Cornelissen JHC, Allison SD, Bauhus J, Eggleton P, Preston CM, Scarff F, Weedon JT, Wirth C, Zanne AE (2009) Plant traits and wood fates across the globe: rotted, burned, or consumed? Global Change Biol 15:2431-2449

Dormann CF, Kühn I (2009) Angewandte Statistik für die biologischen Wissenschaften. 2., durchgesehene, aktualisierte, überarbeitete und erweiterte Auflage. Helmholtz Zentrum für Umweltforschung-UFZ.S 245

Effland MJ (1977) Modified procedure to determine acid-insoluble in wood and pulp. Tappi 60(10):143-144

FAO (2006) World reference base for soil resources 2006. A framework for international classification, correlation and communication. World soil resources report No. 103. 2006 edition. Food and agriculture organization of the united nations (FAO). Rome, 2006. p 128 http://www.fao.org/ag/Agl/agll/ wrb/doc/wrb2006final.pdf

Forrester JA, Mladenoff DJ, Gower ST, Stoffel JL (2012) Interactions of temperature and moisture with respiration from coarse woody debris in experimental forest canopy gaps. For Ecol Man 265:124-132

Freschet GT, Weedon JT, Aerts R, van Hal JR, Cornelissen JHC (2011) Interspecific differences in wood decay rates: insights from a new short-term method to study long-term wood decomposition. J Ecol 100(1):161-170

Graham RL, Cromack KJR (1982) Mass, nutrient content, and decay rate of dead boles in rain forests of Olympic National Parc. Can J For Res 12:511-521

Grove S, Meggs J, Goodwin A (2002) A review of biodiversity conservation issues relating to coarse woody debris management in the wet eucalypt production forests of Tasmania. Forestry Tasmania, Hobart, p 72

Grove SJ, Stamm L, Barry C (2009) Log decomposition rates in Tasmanian Eucalypt obliqua determined using an indirect chronosequence approach. For Ecol Man 258:389-397

Hagemann U, Moroni MT, Gleißner J, Makeshin F (2010) Disturbance history influences downed woody debris and soil respiration. For Ecol Man 260:1762-1772

Harmon ME, Franklin JF, Swanson FJ, Sollins P, Gregory V, Lattin JD, Anderson NH, Cline SP, Aumen NG, Lienkaemper GW, Cromack KJ, Cummins KW (1986) Ecology of coarse woody debris in temperate ecosystems. Adv Ecol Res 15:133-302

Harmon ME, Krankina ON, Sexton J (2000) Decomposition vectors: a new approach to estimating woody detritus decomposition dynamics. Can J For Res 30:76-84

Harmon ME, Fasth B, Woodall CW, Sexton J (2013) Carbon concentration of standing and downed woody detritus: Effects of tree taxa, decay class, position, and tissue type. For Ecol Man 291:259-267

Herrmann S, Bauhus J (2008) Comparison of methods to quantify respirational carbon loss of coarse woody debris. Can J For Res 38:2738-2745

Herrmann S, Bauhus J (2012) Effects of moisture, temperature and decomposition stage on respirational carbon loss from coarse woody debris (CWD) of important European tree species. Scand J For Res 28(4):346-357

Herrmann S, Prescott CE (2008) Mass loss and nutrient dynamics of coarse woody debris in three Rocky Mountain coniferous forests: 21 year results. Can J For Res 38:125-132

Hofrichter M, Liers C, Kinne M, Ullrich R (2009) Abbau und Transformation von Lignin und Huminstoffen durch Pilze. 81-97. In: Ökologische Rolle von Pilzen. Rundgespräche der Kommission für Ökologie, Bd. 37. Hrsg. Bayerische Akademie der Wissenschaften, Verlag Dr. Friedrich Pfeil, 2009

Kahl T (2003) Abbauraten von Fichtentotholz (Picea abies (L.) Karst.) Bohrwiderstandsmessungen als neuer Ansatz zur Bestimmung des Totholzabbaus, einer wichtigen Größe im Kohlenstoffhaushalt mitteleuropäischer Wälder. Magisterarbeit Friedrich-Schiller-Universität Jena, $\mathbf{S} 98$

Kahl T (2008) Kohlenstofftransport aus dem Totholz in den Boden. Dissertation Universität Freiburg. (http://www.freidok.uni-freiburg.de/volltexte/5522/)

Kahl T, Wirth C, Mund M, Böhnisch G, Schulze ED (2009) (2009) Using drill resistance to quantify the density in coarse woody debris of Norway spruce.Eur. J For Res 128:467-473

Kahl T, Mund M, Bauhus J, Schulze ED (2012) Dissolved organic carbon from European beech logs: Patterns of input to and retention by surface soil. Écoscience 19(4):1-10 
Krankina ON, Harmon ME (1995) Dynamics of the dead wood carbon pool in northwestern Russian boreal forest. Water Air Soil Polut 82:227-238

Krankina ON, Harmon ME, Griazkin AV (1999) Nutrient stores and dynamics of woody detritus in a boreal forest: modeling potential implications at the stand level. Can J For Res 29:20-32

Kruys N, Jonnsson BG, Stahl G (2002) A stage-based matrix model for decay-class dynamics of woody debris. Ecol Appl 12(3):773-781

Kuehne C, Donath C, Müller-Using SI, Bartsch N (2008) Nutrient fluxes via leaching from coarse woody debris in a Fagus sylvatica forest in the Solling Mountains, Germany. Can J For Res 38:2405-2413

Laiho R, Prescott CE (2004) Decay and nutrient dynamics of coarse woody debris in northern coniferous forests: a synthesis. Can J For Res 34:763-777

Lambert RL, Lang GE, Reiners WA (1980) Loss of mass and chemical change in decaying boles of a subalpine balsam fir forest. Ecology 61(6):1460-1473

Mackensen J, Bauhus J, Webber E (2003) Decomposition rates of coarse woody debris - a review with particular emphasis on Australian tree species. Austr J Bot 51:27-37

MCPFE (2003) State of Europe's Forests 2003. The MCPFE Report on Sustainable Forest Management in Europe. MCPFE Liaison Unit Vienna and UNECE/FAO. URL on 21.10.2015: www.foresteurope.org/documentos/forests_2003.pdf

MCPFE (2007) State of Europe's Forests 2007. The MCPFE Report on Sustainable Forest Management in Europe. MCPFE Liaison Unit Warsaw, UNECE and FAO. URL on 21.10.2015: http://www.foresteurope.org/documentos/ state_of_europes_forests_2007.pdf

Meyer P (1999) Totholzuntersuchungen in nordwestdeutschen Naturwäldern: Methodik und erste Ergebnisse. Forstwiss Cbl 118:167-180

Meyer P, Bartsch N, Wolff B (2003) Methoden der Totholzerfassung im Wald. Forstarchiv 74:263-274

Müller J, Bütler R (2010) A review of habitat thresholds for dead wood: a baseline for management recommendations in European forests. Eur J For Res 129:981-992

Müller-Using SI (2005) Totholzdynamik eines Buchenbestandes im Solling. Berichte des Forschungszentrums Waldökosysteme der Universität Göttingen, Reihe A, Bd. 193:187S

Müller-Using SI, Bartsch N (2007) Totholz im Elementhaushalt eines Buchenbestandes. Forstarchiv 78:12-23

Müller-Using SI, Bartsch N (2009) Decay dynamic of coarse and fine woody debris of a beech (Fagus sylvatica L.) forest in Central Germany. Eur J For Res 128:287-296

Naesset E (1999) Decomposition rate constants of Picea abies logs in southeastern Norway. Can J For Res 29:372-381

Olson JS (1963) Energy storage and the balance of producers and decomposers in ecological systems. Ecology 44:322-331

Pregitzer KS, Euskirchen ES (2004) Carbon cycling and storage in world forests: biome patterns related to forest age. Global Change Biol 10:1-26

Purahong W, Kahl T, Schloter M, Bauhus J, Buscot F, Krüger D (2014a) Comparing fungal richness and community composition in coarse woody debris in Central European beech forests under three types of management. Mycol Progress. doi:10.1007/s11557-013-0954-y

Purahong W, Hoppe B, Kahl T, Schloter M, Schulze E-D, Bauhus J, Buscot F, Krüger D (2014b) Changes within a single land-use category alter microbial diversity and community structure: Molecular evidence from wood-inhabiting fungi in forest ecosystems. J Environ Manage 139:109-119

Ranius T, Kindvall O, Kruys N, Jonsson BG (2003) Modeling dead wood in Norway spruce stands subject to different management regimes. For Ecol Manage 182:13-29

Rock J, Badeck F-W, Harmon ME (2008) Estimating decomposition rate constants for European tree species from literature sources. Eur J For Res 127:301-313

Russell MB, Woodall CW, Fraver S, D'Amato AW, Domke GM, Skog KE (2014) Residence Times and Decay Rates of Downed Woody Debris Biomass/ Carbon in Eastern US Forests. Ecosystems 17:765-777

Schwarze FW, Engels J, Mattheck C (1999) Holzzersetzende Pilze in Bäumen. Strategien der Holzzersetzung. Rombach Ökologie 5

Seibold S, Brandl R, Buse J, Hothorn T, Schmidl J, Thorn S, Müller J (2014) Association of the extinction risk of saproxylic beetles and the ecological degradation of forests in Europe. Conservation Biology. (in press)

Shigo AL (1986) A new tree biology. Shigo and Trees Associates, Durham

Shorohova E, Kapitsa E (2014) Influence of the substrate and ecosystem attributes on the decomposition rate of coarse woody debris in European boreal forests. For Ecol Manage 315:173-184

Siitonen J (2001) Forest management, coarse woody debris and saproxylic organisms: Fennoscandian boreal forests as an example. Ecol Bull 49:11-41
Spears JDH, Holub SM, Harmon ME, Lajtha K (2003) The influence of decomposing logs on soil biology and nutrient cycling in an old-growth mixed coniferous forest in Oregon, U.S.A. Can J For Res 33:2193-2201

Stenlid J, Penttilä R, Dahlberg A (2008) Wood-decay basidiomycetes in boreal forests: distribution and community development. In: Boddy L, Frankland J, Van West P (eds) Ecology of Saprotrophic Basidiomycetes. Academic, London, pp 239-262

Stone JN, MacKinnon A, Parmintor JV, Lertzman KP (1998) Coarse woody debris decomposition documented over 65 years on southern Vancouver Island. Can J For Res 28:788-793

TAPPI (1976) Acid-soluable lignin in wood and pulp UM 250. Technical association of the pulp and paper industry, Atlanta

Tarasov ME, Birdsey RA (2001) Decay rate and potential storage in the Leningrad region. Ecol Bull 49:137-147

Trendelenburg R, Mayer-Wegelin H (1964) Das Holz als Rohstoff', 2. völlig überarbeitete Auflage. Carl Hanser Verlag, München

Tuomi M, Laiho R, Repo A, Liski J (2011) Wood decomposition model for boreal forests. Ecol Model 222:709-718

Turner DP, Koerper GJ, Harmon ME, Lee JJ (1995) A Carbon Budget for Forests of the Conterminous United States. Ecol Appl 5:421-436

Weedon JT, Cornwell WK, Cornelissen JHC, Zanne AE, Wirth C, Coomes DA (2009) Global meta-analysis of wood decomposition rates: a role for trait variation among tree species? Ecol Lett 12:45-56

Wirth C, Schulze E-D, Luhker B (2000) How fire exerts control over carbon balances in Siberian Scots pine forests. In: The role of boreal forests and forestry in the global casbon budget. Abstracts of International Science Conference, 8-12 May 2002, Edmonton

Yatskov M, Harmon ME, Krankina ON (2003) A chronosequence of wood decomposition in the boreal forests of Russia. Can J For Res 33:1211-1226

Yin X (1999) The decay of forest woody debris: numerical modeling and implications based on some 300 data cases from North America. Oecologia 121(1):81-98

Zell J, Kändler G, Hanewinkel M (2009) Predicting constant decay rates of coarse woody debris - A meta-analysis approach with a mixed model. Ecol Model 220:904-912

\section{Submit your manuscript to a SpringerOpen ${ }^{\odot}$ journal and benefit from:}

- Convenient online submission

$\checkmark$ Rigorous peer review

- Immediate publication on acceptance

- Open access: articles freely available online

- High visibility within the field

- Retaining the copyright to your article

Submit your next manuscript at $>$ springeropen.com 